\title{
The Role of Parental Assistance in Improving Children's Learning Quality During the Covid-19 Pandemic
}

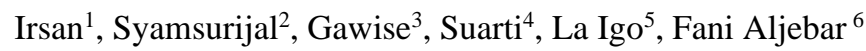 \\ \{Irsanleley@gmail.com $\left.{ }^{1}\right\}$ \\ Primary teacher Education, Universitas Muhammadiyah Buton, Indonesia ${ }^{1,2,3,4,5,6}$
}

\begin{abstract}
The research aims to see the effectiveness of parents in children's learning independence during the Covid-19 pandemic. This research is a qualitative descriptive study. The objects of this research are students and their parents and students. The data technique used observation and interviews. Interviews were conducted with a list of interview questions that will be developed in the related literature. The results showed that the role of parents as educators in children's learning, the role of parents in guiding children, the role of parents in providing motivation to learn, parents establish intense communication for children, parents are good examples for children, and there is a role. parents who provide variety and innovation in learning so that children don't get bored. However, there is still the role of parents who have not been maximal in providing learning to independent children, the causative factor lies in the background of parents with a low degree of education, a disharmonious family, low family economic level, and the lack of awareness of the parents themselves, and facilities and infrastructure. which does not support the learning process during the Covid 19 pandemic.
\end{abstract}

Keywords: Learning quality, independent learning, parental assistance

\section{Introduction}

In the world of education, the Covid-19 outbreak has changed learning patterns that should be carried out in general or face-to-face to distance learning or what is called online. Educational activities in schools that are very closely related to the interaction between teachers and students and students and students have to be stopped (social distancing) by replacing them with distance learning (online). Online learning is learning that utilizes virtual and internet technology [1]. Online learning is applied to all levels of education from early childhood to university.

This is not an easy thing for all elements of education, especially the role of parents in dealing with the learning system transition. her children [2]. However, today's conditions are different, parents are more important and have more time to guide their children and develop deeper emotional closeness than before. At the hospital, doctors are at the forefront of treating Covid-19 patients. So it cannot be denied that while studying at home the parents are the front guard in guiding their children. Generally, education is a system that is interrelated between one component and another. Teachers, students, media and the environment are all part of this component. What supports children's learning and learning motivation is the environment. The environment is the school environment, family environment and daily social environment. 
Online learning is provided by the teacher through monitoring from the school by giving assignments every day to parents at home. Therefore, in the midst of busy parents at home, they demand parents to be able to accompany children to learn every day, so that parents are required to spend the time accompanying children studying at home. The form of the role of parents is actually a form of the role of teachers in school, such as providing motivation in all things, being happy friends for learning, helping in solving problems and difficulties faced by children while learning and developing children's self-confidence [3]. It is hoped that involving learning assistance by parents can increase children's potential at home, parental involvement tends to have a positive effect on the success and learning development of children [4].

The family life of parents generally plays an important role in instilling cultural values and social values in children so that they can behave in accordance with existing rules in society and can participate as members of their community groups [5]. The first position in educating and teaching values and norms to individuals lies with the family, to reveal how important the influence of family, environment and experiences is on children's development. Parents, as companions for their children, have a role in providing support to achieve the desired quality of education. Every parent has a desire and goal for the success of their children in the future. Therefore, the participation of parents is very necessary in supporting the progress and education of a child. Parents are a roll model for their children's lives [6]. Parents are one of the informal schools. So parents actually have a significant share and contribution to children's learning motivation.

The family life of parents generally plays an important role in instilling cultural values and social values in children so that they can behave in accordance with existing rules in society and can participate as members of their community groups. Talking about the role of parents, it cannot be separated from the family [7]. Parents are the first and foremost figures in children's education [8]. States that the family is seen from its function, namely having a duty and function of care, emotional and material support, and fulfillment of certain roles. Family has an important role in caring for, educating, protecting and caring for children. Stated that parental care for their children can affect the formation of children's character and behavior. Parents, as companions for their children, have a role in providing support to achieve the desired quality of education. Every parent has a desire and goal for the success of their children in the future. Therefore, the participation of parents is very necessary in supporting the progress and education of a child. Parents are the first and foremost educational institution or school for children. Therefore, the role of parents as a substitute for teachers is neededhome in guiding their child during the distance learning process [9]. In academic achievement, it shows that the influence of parental involvement on student academic success should not be underestimated. The family is important in inculcating habits and behavior patterns, and instilling values, religion and morals according to age and family culture [10]. Parents are an informal school. So real parents have a significant share and contribution to motivation. Based on this, this study focuses on the implications of the role of parental assistance in improving the quality of children's learning during the Covid19 pandemic.

\section{Method}

The research method in this study is descriptive qualitative method, namely research on data collected and expressed in the form of words arranged in sentences, namely sentences resulting from interviews conducted by researchers and informants. Structured interviews were 
conducted based on related literature. The respondents in this study were parents of elementary school students. The approach taken in this study is the ethnographic design approach (ethnographic studies), where researchers describe and interpret social groups and systems of parental involvement in certain groups. The position of researchers in qualitative research is one of the main instruments in conducting research. Researchers collect data from start to finish. The data collection technique carried out is by means of structured interviews. The purpose of this study was to determine the implications of the role of parental assistance in improving the quality of children's learning during the Covid-19 pandemic.

\section{Result and discussion}

The role of parents in supporting learning activities at home during the pandemic period so as to improve the quality of learning. The contribution of parents to education greatly affects the quality of children's learning. The contribution of parents to education must be carried out in a sustainable manner in motivating, providing direction and encouraging as well as providing the means to achieve ideals in educating children. Through activities to obtain information in conducting research, interview-taking activities were carried out by asking questions to informants regarding the role of parents in learning activities carried out during the Covid-19 pandemic. Researchers distributed questionnaires to people to find out the percentage of student assistance in learning at home. The percentage of the number of people who accompany students to study at home present at Figure 1.

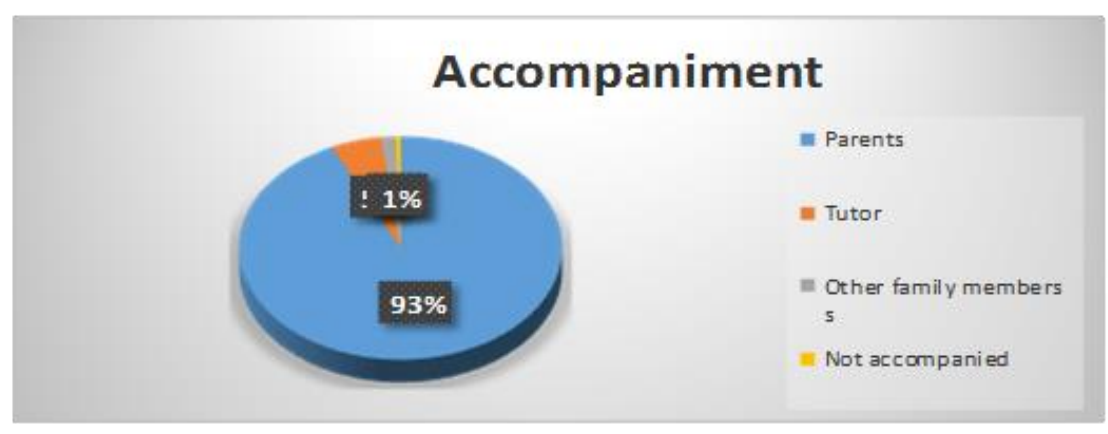

Fig. 1. Percentage of people accompanying students to study from home

Based on Figure 1, it can be seen that not all parents accompany their children to study at home. Based on the interviews conducted, there are many factors that cause parents not to be able to accompany children to study at home. One of the factors that causes it is that there are some parents who are busy working so that there is no time to accompany their children to study at home, other than the reason parents are busy working is that there are still parents who do not master the subject matter given to children by the class teacher, this problem is influenced because There are still parents who have very low education so that it has an impact on their knowledge. In improving the quality of learning for children, parents need learning assistance from others, namely tutors and other family members. Based on the data obtained by researchers, there is a big problem, namely there are children who do not get assistance in the learning process at home. during the covid pandemic 19. 
During the learning process at home, parents accompany their children to learn, parents have the task of always monitoring the development of children's learning activities. Based on the data obtained, there are several activities carried out by parents in monitoring the development of children's learning activities at home. There are shows at Figure 1.

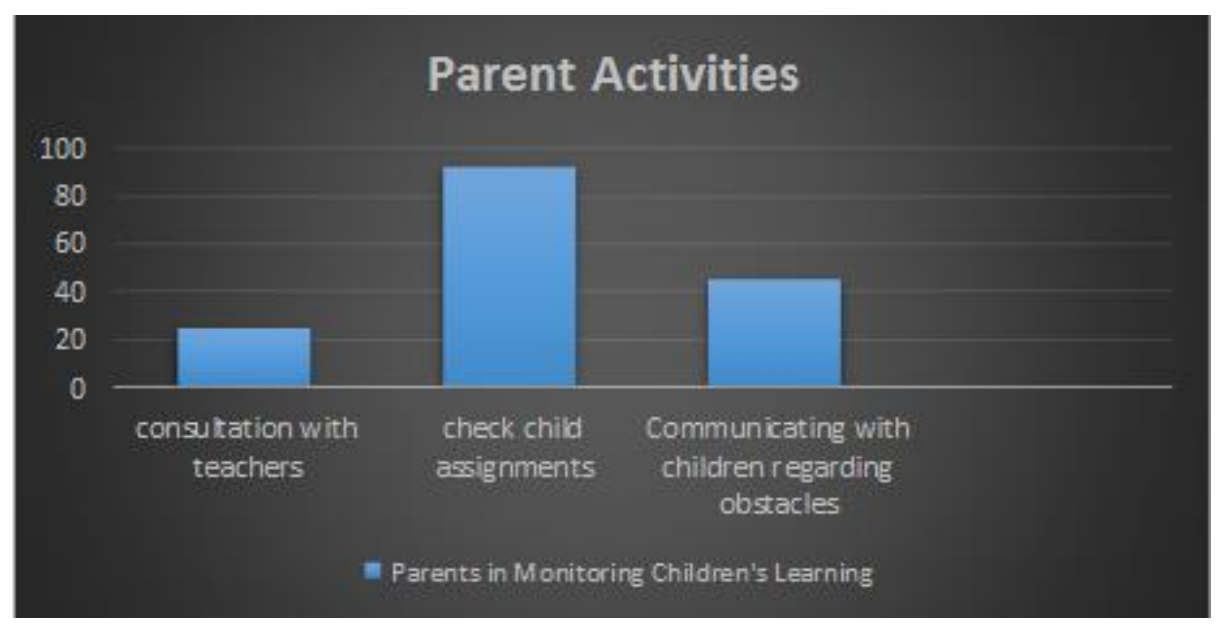

Fig. 2. Parent activities

Based on Figure 1, there are several activities or activities carried out by parents in monitoring children's learning development. From this data, it can be concluded that the activities that parents often do are always checking what tasks are given by the teacher, checking whether the tasks done by the child are correct, giving additional assignments to find out whether the child understands the material provided by the teacher. Other activities carried out by parents are communicating with children about what difficulties children experience during the learning process, and activities that parents rarely do are consulting with teachers regarding obstacles experienced by parents in accompanying children. Based on the questionnaire distributed, all parents agreed that parents and teachers must always communicate in monitoring learning progress such as the material provided, in addition to the material provided, the teacher must also communicate whether the daily assignments have been done, whether the subject matter given can be understood, whether the child is can follow the lesson well, are there any obstacles in following the lesson, what are the difficulties experienced in online learning. Parents must inform the teacher of all children's activities with the aim that the online learning process can run smoothly in accordance with the learning objectives that have been set so that the child's abilities increase.

Online learning, the responsibility for the success of children is not automatically given to parents, but teachers still hold this responsibility by monitoring the learning process at home / evaluating online learning activities. Learning evaluation must be carried out by the teacher to determine the level of effectiveness of the implementation of online learning or in other words to find out how far the learning objectives have been achieved. The effectiveness of learning is seen from 3 aspects, namely student activity during learning, student responses to learning, and mastery of student concepts after learning The effectiveness of learning is not only measured by learning outcomes, but also from the processes and learning support facilities. In order for the learning process to run as it should, there needs to be two-way communication between the 
school and the parents of students. Building communication is important so that parents understand the learning objectives expected by the teacher and vice versa, the teacher also understands the wishes of parents in assisting children to study at home. Parents' expectations for online learning include: the material presented can be understood by children well, instructions for doing assignments must be clear, the assignments given are not burdensome for children. Communication between students and teachers is more intense if there are obstacles, the material presented is easy to understand, the material is integrated with student life, learning is fun for students, and obtains skills and character education.

\section{Conclusion}

Improving the quality of learning during the Covid-19 pandemic, especially in elementary schools (SD), cannot be separated from the important wars of parents and teachers. Parents who are busy working cannot accompany their children in learning so they need help from others, such as family members. Besides work problems, there are still parents who do not understand the subject matter provided by the teacher, so they need assistance from other parties, such as tutors. Activities that parents can do in accompanying children to study at home include: checking the material and assignments given by the teacher, checking the tasks that the child has done, helping to improve children's understanding of the material given, always communicating with children about the obstacles faced during the learning process, teachers and parents always communicate in improving the quality of children's learning. The communication that is built by teachers and parents is very important so that the application of online learning is in line with expectations including: children can understand the material given well, the assignments given must be clear, the assignments given by the teacher can be done by children and do not burden the child, the material provided by the teacher fun for children, online learning can increase student knowledge.

\section{Acknowledgement}

On this occasion the researchers would like to express their deepest gratitude to the leaders of the Buton Muhammadiyah University who have provided assistance so that this research can be carried out. The author also expresses his deepest gratitude to all those who have helped in the implementation of this research and hopefully this research can be a reference for other researchers.

\section{References}

[1] I. C. Technology, “唐跃桓 1 杨其静 1 李秋芸 2 朱博鸿 3,” vol. 1, no. 2, pp. 75-94, 2020.

[2] B. Kusumaningrum, K. S. Kuncoro, T. A. Arigiyati, and Trisniawati, "Pendampingan Orangtua Dalam Pembelajaran Daring Di Sekolah Dasar: Evaluasi Pembelajaran Daring Selama Masa Pandemi Covid-19," Inven. J. Pendidik. Guru Sekol. Dasar, vol. 4, no. 2, pp. 142-150, 2020, [Online]. Available: http://jurnal.unipasby.ac.id/index.php/jurnal_inventa. 
[3] A. Lilawati, "Peran Orang Tua dalam Mendukung Kegiatan Pembelajaran di Rumah pada Masa Pandemi," J. Obs. J. Pendidik. Anak Usia Dini, vol. 5, no. 1, p. 549, 2020, doi: 10.31004/obsesi.v5i1.630.

[4] C. Sopiah, S. Pd, and M. Si, "Pembelajaran Anak Usia Dini Saat Pandemi Copid-19," pp. 34-44, 2020.

[5] M. D. Lestari, "Peran Orang Tua Siswa Sekolah Dasar Dalam Proses Pembelajaran Daring Selama Wabah Covid-19," Academia.Edu, no. c, pp. 1-12, 2020, [Online]. Available: http://www.academia.edu/download/63889093/Artikel_Revisi_Maria20200711-25067-1q71stc.pdf.

[6] W. Suweleh, "by Wardah Suweleh," 2019.

[7] S. L. Iftitah and M. F. Anawaty, "Peran Orang Tua Dalam Mendampingi Anak Di Rumah Selama Pandemi Covid-19," JCE (Journal Child. Educ., vol. 4, no. 2, p. 71, 2020, doi: 10.30736/jce.v4i2.256.

[8] M. Umar, "Peranan Orang Tua Dalam Peningkatan Prestasi Belajar Anak," J. EDUKASI J. Bimbing. Konseling, vol. 1, no. 1, p. 20, 2015, doi: 10.22373/je.v1i1.315.

[9] N. Cahyati and R. Kusumah, "Peran Orang Tua Dalam Menerapkan Pembelajaran Di Rumah Saat Pandemi Covid 19," J. Golden Age, vol. 4, no. 01, pp. 4-6, 2020, doi: 10.29408/jga.v4i01.2203.

[10] S. Zahrok and N. W. Suarmini, "Peran Perempuan Dalam Keluarga," IPTEK J. Proc. Ser., vol. 0, no. 5, p. 61, 2018, doi: 10.12962/j23546026.y2018i5.4422. 